\title{
Scorpion venom component III inhibits cell proliferation by modulating NF- $\kappa B$ activation in human leukemia cells
}

\author{
XIANGFENG SONG ${ }^{1,2}$, GUOJUN ZHANG ${ }^{2}$, AIPING SUN ${ }^{2}$, JIQIANG GUO ${ }^{2}$, \\ ZHONGWEI TIAN $^{3}$, HUI WANG ${ }^{2}$ and YUFENG LIU ${ }^{1}$ \\ ${ }^{1}$ Department of Pediatrics, The First Affiliated Hospital of Zhengzhou University, Zhengzhou University, Zhengzhou; \\ ${ }^{2}$ Department of Immunology, Xinxiang Medical University, Xinxiang; ${ }^{3}$ Department of Dermatology, \\ The First Affiliated Hospital of Xinxiang Medical University, Xinxiang, Henan, P.R. China
}

Received November 15, 2011; Accepted April 3, 2012

DOI: $10.3892 /$ etm.2012.548

\begin{abstract}
Scorpion venom contains various groups of compounds that exhibit anticancer activity against a variety of malignancies through a poorly understood mechanism. While the aberrant activation of nuclear factor $\kappa \mathrm{B}(\mathrm{NF}-\kappa \mathrm{B})$ has been linked with hematopoietic malignancies, we hypothesized that scorpion venom mediates its effects by modulating the $\mathrm{NF}-\kappa \mathrm{B}$ signaling pathway. In the present study, we examined the effects of scorpion venom component III (SVCIII) on the human leukemia cell lines THP-1 and Jurkat and focused on the NF-кB signaling pathway. Our results showed that SVCIII inhibited cell proliferation, caused cell cycle arrest at G1 phase and inhibited the expression of cell cycle regulatory protein cyclin D1 in a dose-dependent manner in THP-1 and Jurkat cells. SVCIII also suppressed the constitutive NF- $\kappa \mathrm{B}$ activation through inhibition of the phosphorylation and degradation of I $\mathrm{B} \alpha . \mathrm{NF}-\kappa \mathrm{B}$ luciferase reporter activity was also inhibited by SVCIII. Our data suggest that SVCIII, a natural compound, may exert its antiproliferative effects by inhibiting the activation of $\mathrm{NF}-\kappa \mathrm{B}$ and, thus, has potential use in the treatment of hematopoietic malignancies, alone or in combination with other agents.
\end{abstract}

\section{Introduction}

Scorpion venom contains various groups of compounds that exhibit a wide range of biological properties and actions in cells. The general composition and expression level of scorpion

Correspondence to: Professor Hui Wang, Department of Immunology, Xinxiang Medical University, Xinxiang, Henan 453003, P.R. China

E-mail:wanghui@xxmu.edu.cn

Professor Yufeng Liu, Department of Pediatrics, The First Affiliated Hospital of Zhengzhou University, Zhengzhou University, Zhengzhou, Henan 450052, P.R. China

E-mail: 1yf6012@tom.com

Key words: scorpion venom, nuclear factor- $\kappa \mathrm{B}$, cell cycle, leukemia venom depends on genetic variation and geographical environment $(1,2)$. The scorpion Buthus martensii Karsch (BmK) and its products have been used as a traditional Chinese medicine for thousands of years. Traditional healers use scorpions to treat various types of condition, such as epilepsy, rheumatism and cancer. It has previously been reported that crude scorpion venom or isolated peptides from scorpion venom may inhibit the proliferation of cancer cells and induce cell apoptosis $(3,4)$. However, the antitumor molecular mechanisms are poorly understood.

Nuclear factor $\kappa \mathrm{B}(\mathrm{NF}-\kappa \mathrm{B})$ is an important transcription factor, which plays a part in many cellular activities such as proliferation and activation of immunocytes, development of T and B lymphocytes and cell apoptosis (5). However, substantial evidence also indicates that NF- $\kappa \mathrm{B}$ plays a pivotal role in the onset and development of malignancies. Recent observations have shown that there is a close relationship between $\mathrm{NF}-\kappa \mathrm{B}$ and hematopoietic malignancies such as leukemia, lymphoma and multiple myeloma $(6,7)$, as aberrant activation of the NF- $\kappa \mathrm{B}$ pathway is involved in the pathogenesis of these diseases. Moreover, some studies have suggested that blocking the NF- $\kappa \mathrm{B}$ signaling pathway can cause tumor cells to cease proliferation, die, or become more sensitive to the action of antitumor agents (7). The NF- $\mathrm{NB}$ signaling pathway has therefore become a promising target for cancer therapy. In the present study, we attempted to elucidate the antiproliferation and cell cycle arresting properties of scorpion venom component III (SVCIII) from BmK venom and its effects on the $\mathrm{NF}-\kappa \mathrm{B}$ signaling pathway in human leukemic cell line Jurkat and THP-1 cells.

\section{Materials and methods}

Chemicals. RPMI-1640 medium and fetal bovine serum (FBS) were purchased from Gibco-BRL (Carlsbad, CA, USA). TransFast $^{\mathrm{TM}}$ Transfection Reagent was obtained from Promega Corporation (Madison, WI, USA). NF- $\kappa \mathrm{B}$ luciferase reporter plasmid was a gift from Dr Luan Haojiang (US National Institutes of Health). Antibodies to cyclin D1, IкB $\alpha$ and p-ІкB $\alpha$ were purchased from Santa Cruz Biotechnology, Inc. (Santa Cruz, CA, USA). Nuclear extract kit was purchased from Active Motif (Carlsbad, CA, USA). Chemiluminescent electrophoretic 
mobility shift assay (EMSA) kit was purchased from Beyotime Institute of Biotechnology (Nantong, China). All other reagents used in the study were of analytical grade and purchased locally.

Scorpion venom. BmK venom was extracted by mild electrical stimulation of the telsons and dissolved in $0.02 \mathrm{M}$ phosphate buffer, $\mathrm{pH} 7.2$, and centrifuged at $10,000 \mathrm{x}$ g for $15 \mathrm{~min}$ at $4^{\circ} \mathrm{C}$. Gel chromatography was utilized to isolate partial peptide fractions from crude scorpion venom. Seven fractions were obtained and named scorpion venom components (SVC)I, II, III, IV, V, VI, VII, respectively. The molecular weight of SVCIII was calculated to be approximately 70-80 kDa through comparison with protein markers of known molecular weights run in a $12 \%$ SDS-PAGE.

Cell culture and treatments. The THP-1 (human acute monocytic leukemia) cell line was provided by the Southern Medical University, and the Jurkat (human T lymphoma) cell line was obtained from the American Type Culture Collection (Manassas, VA, USA). Cells were grown in 50-ml plastic flasks in RPMI-1640 medium containing 10\% heat-inactivated fetal bovine serum (FBS), $100 \mu \mathrm{g} / \mathrm{ml}$ streptomycin, and $100 \mathrm{U} / \mathrm{ml}$ penicillin and incubated in a $5 \% \mathrm{CO}_{2}$ humidity incubator at $37^{\circ} \mathrm{C}$. The medium was refreshed three times a week. Cells in log phase were seeded in sterile 6-, 24- or 96-well plates with a fixed number in each well and then treated with varying amounts of SVCIII for $48 \mathrm{~h}$.

Cell viability assay by MTT. Cell viability was determined by MTT assay. Cells were seeded in a 96-well plate at a density of $1 \times 10^{5}$ cells per well and treated with various concentrations $(0$, $1,5,10,20,30,40$ and $50 \mu \mathrm{g} / \mathrm{ml}$ ) of SVCIII for $48 \mathrm{~h}$. MTT dye was added to each well for the last $4 \mathrm{~h}$ of treatment. When purple precipitates were visible, the medium was carefully discarded. The formazan crystals were dissolved by adding $200 \mu \mathrm{l}$ of dimethyl sulfoxide to each well. The cell viability index was calculated by measuring the absorbance value at $570 \mathrm{~nm}$.

Flow cytometry for cell cycle analysis. A cell cycle assay was performed using propidium iodide (PI) staining of the nuclei. Following treatment for $48 \mathrm{~h}$ with SVCIII, cells were fixed in $70 \%$ cold alcohol overnight and then centrifuged. The pellet was re-suspended in $500 \mu \mathrm{l}$ PI staining buffer $(250 \mu \mathrm{g} / \mathrm{ml} \mathrm{PI}$, $10 \mu \mathrm{g} / \mathrm{ml}$ RNase in PBS) in a dark room for $30 \mathrm{~min}$ at room temperature and analyzed with a flow cytometer. For each measurement, at least 10,000 cells were counted.

$N F-\kappa B$ luciferase reporter luciferase assay. To determine the effect of SVCIII on NF- $\mathrm{B}$ activation, cells were transiently transfected with a $\mathrm{NF}-\kappa \mathrm{B}$ luciferase reporter plasmid. Cells were seeded in 24-well plates (10\%/well) and transfected with

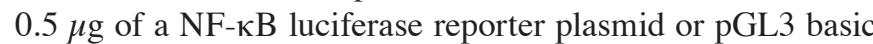
as a negative control using TransFast ${ }^{\mathrm{TM}}$ Transfection Reagent according to the manufacturer's instructions and co-transfected with 40 ng of pRL-TK Renilla luciferase vector to control transfection efficiency. Transfected cells were exposed to SVCIII for $6 \mathrm{~h}$. Cells were then harvested and lysed according to the manufacturer's instructions. Supernatants were analyzed for firefly and Renilla luciferase activity using the dual-luciferase reporter assay system.
EMSA. To assess NF-кB activation, EMSA was performed according to the manufacturer's instructions for the Chemiluminescent EMSA Kit. Biotin-labeled double-stranded oligonucleotides were used which included commercially available consensus NF- $\mathrm{KB}$ gel shift oligonucleotide 5'-biotinAGTTGAGGGGACTTTCCCAGG-3'. Specific binding was confirmed by competition experiments with a 100 -fold excess of unlabeled or mutated oligonucleotides. The bands were detected by enhanced chemiluminescent (ECL) assay kit.

Cell extracts and western blotting. Nuclear extracts were isolated using a nuclear extract kit. Cells were briefly washed twice with ice-cold PBS/phosphatase inhibitors and incubated in $500 \mu \mathrm{l}$ of hypotonic buffer for $15 \mathrm{~min}$ on ice. Subsequently, $25 \mu \mathrm{l}$ detergent was added and the cells were vortexed at the highest setting and centrifuge suspended for $30 \mathrm{sec}$ at $14,000 \mathrm{x}$ g at $4^{\circ} \mathrm{C}$. Nuclei were washed with $50 \mu \mathrm{l}$ complete lysis buffer and vortexed for $10 \mathrm{sec}$ at the highest setting. Thereafter the lysate was incubated for $30 \mathrm{~min}$ on ice and centrifuged for $10 \mathrm{~min}$ at $14,000 \mathrm{x} \mathrm{g}$. Protein concentrations were determined using the Bradford assay. Proteins were resolved by $12 \%$ SDS-PAGE gels, transferred onto a PVDF membrane and subjected to western blot analysis using anti-cyclin D1, IкB $\alpha$ and $\mathrm{p}-\mathrm{I} \kappa \mathrm{B} \alpha$ antibody. Proteins were visualized with an ECL assay kit according to the manufacturer's instructions.

Statistical analysis. Data are presented as mean \pm S.D. and one-way analysis of variance was used to identify significant differences among the results. Statistical significance was defined as $\mathrm{P}<0.05$.

\section{Results}

Effect of SVCIII on cell viability. MTT assay was used to determine the effect of SVCIII on cell viability. As shown in Fig. 1, the cell viability of THP-1 and Jurkat cells was decreased by SVCIII in a dose-dependent manner. The percentage of viable THP-1 cells following treatment with 1, 5, 10, 20, 30, 40 and $50 \mu \mathrm{g} / \mathrm{ml}$ of SVCIII decreased to 83.4, 74.7, 65.3, 55.0, 46.9, 38.2 and $33.4 \%$ respectively. Viability of Jurkat cells after exposure to increasing concentrations of SVCIII was reduced to $91.9,86.7,77.3,68.8,58.2,49.4$ and $41.3 \%$ respectively (Fig. 1). However, there were no significant differences in the human peripheral blood lymphocytes (PBLs) between SVCIII-treated cells and controls. The $\mathrm{IC}_{50}$ value was calculated to be $29 \mu \mathrm{g} / \mathrm{ml}$ for THP-1 and $39.6 \mu \mathrm{g} / \mathrm{ml}$ for Jurkat. The concentrations $1 / 2 \mathrm{IC}_{50}$ and $\mathrm{IC}_{50}$ were used to investigate the effects of venom in subsequent experiments.

Effect of SVCIII on cell cycle distribution. We then tested the effect of SVCIII on cell cycle distribution using flow cytometry. A dose-dependent increase in the G1 phase cell population was observed from $45.1 \%$ in controls to 65.1 and $74.9 \%$, respectively, due to SVCIII treatment at $1 / 2 \mathrm{IC}_{50}(15 \mu \mathrm{g} / \mathrm{ml})$ and $\mathrm{IC}_{50}$ (30 $\mu \mathrm{g} / \mathrm{ml}$ ) concentration for THP-1, and from $44.4 \%$ in controls to 56.4 and $65.7 \%$, respectively, due to SVCIII treatment at $1 / 2 \mathrm{IC}_{50}(20 \mu \mathrm{g} / \mathrm{ml})$ and $\mathrm{IC}_{50}(40 \mu \mathrm{g} / \mathrm{ml})$ concentration for Jurkat. A decrease in the $\mathrm{S}$ phase cell population was observed from $44.7 \%$ in controls to 25.6 and $17.3 \%$, respectively, due to SVCIII treatment at $1 / 2 \mathrm{IC}_{50}(15 \mu \mathrm{g} / \mathrm{ml})$ and $\mathrm{IC}_{50}(30 \mu \mathrm{g} / \mathrm{ml})$ 


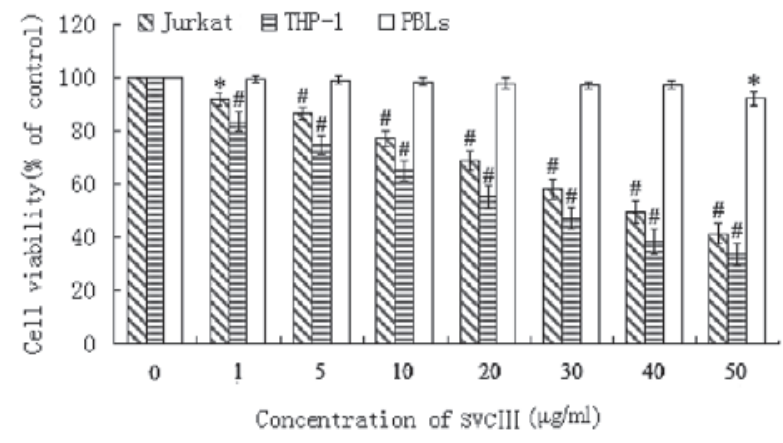

Figure 1. Effects of SVCIII on the viability of normal human lymphocytes (THP-1 and Jurkat cells). Cells were treated with various concentrations of SVCIII for $48 \mathrm{~h}$. The index of cell viability was calculated by measuring the absorbance value at $570 \mathrm{~nm}$. Data are expressed as percentages of the control value. ${ }^{*} \mathrm{P}<0.05$ and ${ }^{\#} \mathrm{P}<0.01$, SVCIII-treated groups compared to the control $(0 \mu \mathrm{g} / \mathrm{ml})$.

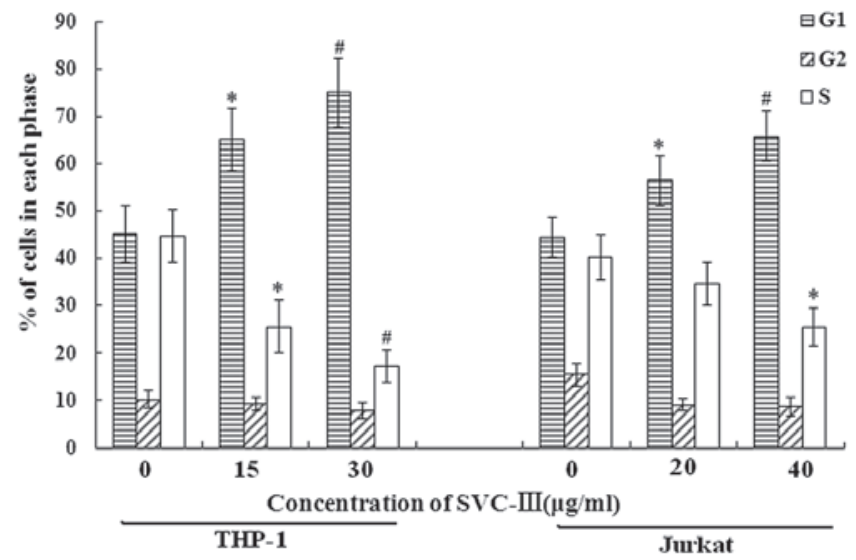

Figure 2. Effects of SVCIII on the cell cycle. THP-1 cells were treated with SVCIII at concentrations of 15 and $30 \mu \mathrm{g} / \mathrm{ml}$ while Jurkat cells were treated with SVCIII at concentrations of 20 and $40 \mu \mathrm{g} / \mathrm{ml}$ respectively for $48 \mathrm{~h}$. A cell cycle assay was performed using propidium iodide staining of the nuclei by flow cytometry. Histograms show the percentages of cells at various phases of cell cycle. Each value is expressed as mean \pm S.D. $(n=3) .{ }^{*} \mathrm{P}<0.05$ and ${ }^{\#} \mathrm{P}<0.01$, SVCIII-treated groups compared to the control $(0 \mu \mathrm{g} / \mathrm{ml})$.

concentration for THP-1, and from $40.2 \%$ in controls to 34.6 and $25.6 \%$, respectively, due to SVCIII treatment at $1 / 2 \mathrm{IC}_{50}(20 \mu \mathrm{g} / \mathrm{ml})$ and $\mathrm{IC}_{50}(40 \mu \mathrm{g} / \mathrm{ml})$ concentration for Jurkat (Fig. 2). These results indicate that SVCIII inhibits cell growth through arrest at G1 phase and reduces transition to the $\mathrm{S}$ and $\mathrm{G} 2 / \mathrm{M}$ phases of the cell cycle in both THP-1 and Jurkat cells.

Effect of SVCIII on cyclin D1 protein. Cyclin D1, an $\mathrm{NF}-\kappa \mathrm{B}$-regulated gene, is required for transition from $\mathrm{G} 1$ to $\mathrm{S}$ phase and plays a vital role in cell proliferation. We, therefore, examined whether SVCIII suppresses the expression of cyclin D1 protein. As shown in Fig. 3, SVCIII significantly inhibited the expression of cyclin D1 in a dose-dependent manner in both cell types. This result suggests a potential mechanism for how SVCIII suppresses tumor cell proliferation.

Effect of SVCIII on NF- $\kappa B$ activation. In order to determine whether $\mathrm{NF}-\kappa \mathrm{B}$ is involved in cell growth suppression induced
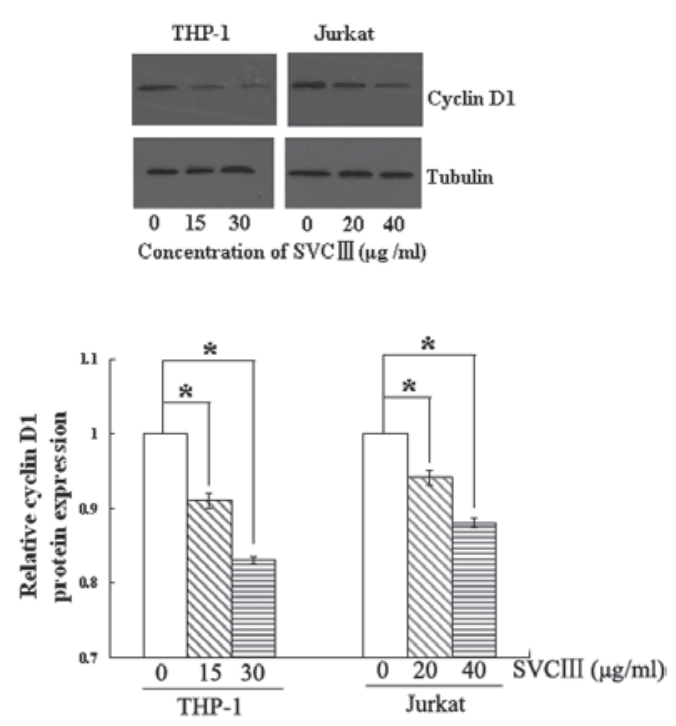

Figure 3. Effects of SVCIII on cyclin D1 protein. THP-1 cells were treated with SVCIII at concentrations of 15 and $30 \mu \mathrm{g} / \mathrm{ml}$ while Jurkat cells were treated with SVCIII at concentrations of 20 and $40 \mu \mathrm{g} / \mathrm{ml}$ for $24 \mathrm{~h}$. Protein from the total cell lysate was subjected to SDS-PAGE and western blot analysis for cyclin D1 protein. Tubulin was used as an internal control. Representative results are shown from three independent experiments. ${ }^{*} \mathrm{P}<0.05$, SVCIII-treated groups compared to the control $(0 \mu \mathrm{g} / \mathrm{ml})$.

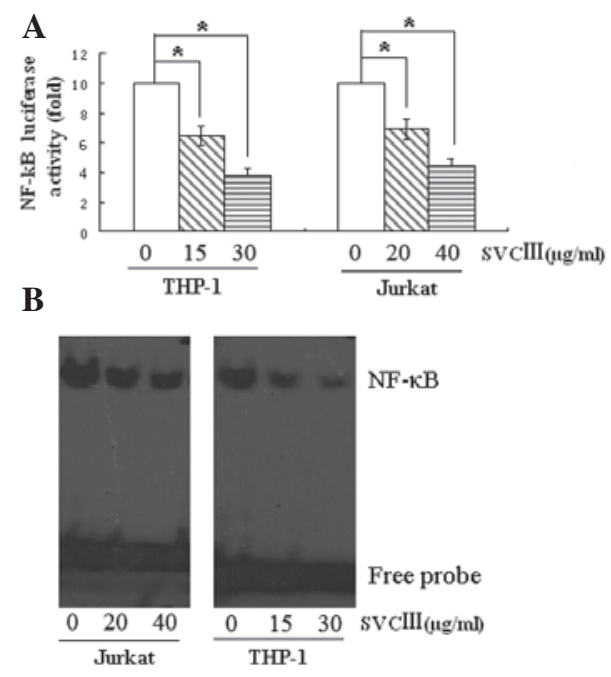

Figure 4. Effect of SVCIII on NF-кB activation. (A) Cells were transiently transfected with a NF- $\mathrm{BB}$ luciferase reporter plasmid or pGL3 empty vector and then were exposed to SVCIII (at concentrations of 15 and $30 \mu \mathrm{g} / \mathrm{ml}$ for THP-1 cells, 20 and $40 \mu \mathrm{g} / \mathrm{ml}$ for Jurkat cells) for $6 \mathrm{~h}$. Cells were lysed and supernatants were analyzed for firefly and Renilla luciferase activity using the dual-luciferase reporter assay system. ${ }^{*} \mathrm{P}<0.01$. (B) Cells were incubated with SVCIII for $6 \mathrm{~h}$. Nuclear extracts were then prepared and assayed for $\mathrm{NF}-\kappa \mathrm{B}$ activation by electrophoretic mobility shift assay.

by SVCIII, we first measured NF- $\mathrm{NB}$-luciferase activity by using a luciferase plasmid containing six tandem NF- $\kappa \mathrm{B}$ sites as a minimal promoter. Fig. 4A showed that treatment with SVCIII resulted in a significant decrease in NF- $\kappa \mathrm{B}-$ luciferase activity.

We then examined the NF- $\kappa \mathrm{B}$ activation using EMSA. Exposure of cells to SVCIII led to a decrease in NF-кB-DNA binding in a dose-dependent manner (Fig. 4B). The suppression 

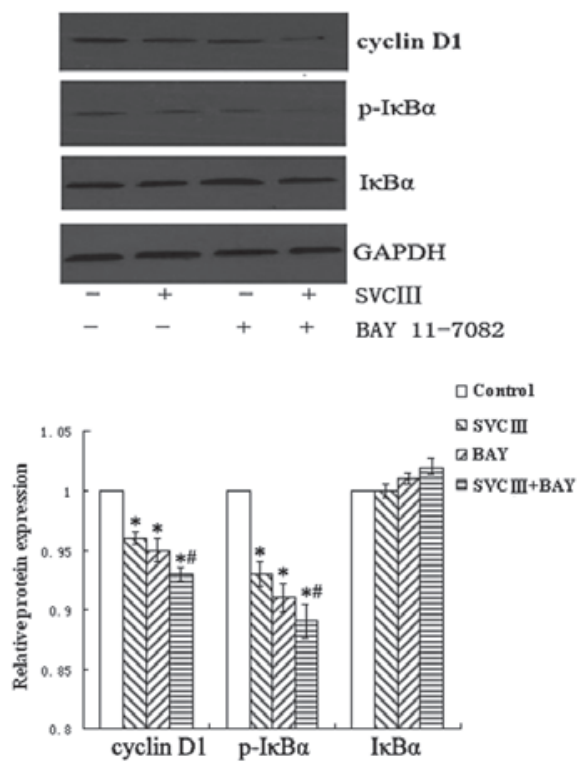

Figure 5. THP-1 cells were incubated with BAY11-7082 $(1 \mu \mathrm{M})$ alone or in combination with SVCIII $(30 \mu \mathrm{g} / \mathrm{ml})$ for $24 \mathrm{~h}$. Protein from the total cell lysate was subjected to SDS-PAGE and western blot analysis using antiI $\mathrm{B} \alpha, \mathrm{p}-\mathrm{I} \kappa \mathrm{B} \alpha$, cyclin D1 and GAPDH antibodies. Representative results are shown from three independent experiments. ${ }^{*} \mathrm{P}<0.05$, SVCIII-treated groups compared to the control; ${ }^{\prime} \mathrm{P}<0.05$, SVCIII in combination with BAY11-7082 groups compared with SVCIII or BAY11-7082 alone.

of NF- $\kappa \mathrm{B}-\mathrm{DNA}$ binding activity was consistent with luciferase reporter activity. These results suggest that SVCIII inhibits $\mathrm{NF}-\kappa \mathrm{B}$ activation.

Effect of SVCIII on $I \kappa B \alpha$. The translocation of NF- $\kappa \mathrm{B}$ to the nucleus is preceded by the phosphorylation and proteolytic degradation of $\mathrm{I} \kappa \mathrm{B} \alpha$. To elucidate the signaling pathways involved in the suppression of $\mathrm{NF}-\kappa \mathrm{B}$ activation, we pretreated THP-1 cells with NF- $\kappa$ B inhibitor BAY11-7082 for $1 \mathrm{~h}$ and then subjected the cells to SVCIII. Although the expression of $\mathrm{p}-\mathrm{I} \kappa \mathrm{B} \alpha$ was markedly inhibited by SVCIII treatment, it was further decreased by the pre-treatment with the $\mathrm{NF}-\kappa \mathrm{B}$ inhibitor (Fig. 5). Next, we investigated whether the NF- $\kappa \mathrm{B}$ inhibitor would also suppress the expression of cyclin D1. As expected, $\mathrm{NF}-\kappa \mathrm{B}$ inhibitor led to a decrease in the expression of cyclin D1, whereas it was further decreased by the NF- $\mathrm{B}$ inhibitor combined with SVCIII (Fig. 5).

\section{Discussion}

In the present study, we investigated the effects of SVCIII on cell growth in the THP-1 and Jurkat cell lines, as well as on the NF- $\kappa \mathrm{B}$ signaling pathway. We found that SVCIII inhibited the cell proliferation and cell cycle arrest at G1 phase in

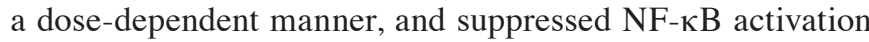
through inhibition of I $\mathrm{B} \alpha$ phosphorylation, degradation and p65 nuclear translocation.

It is well established that normal cells divide and create new cells only when needed. One of the hallmark characteristics of cancer cells is their uncontrolled proliferation (8). Our results demonstrated that SVCIII inhibited cell proliferation in human THP-1 and Jurkat cells in a dose-dependent manner.
These results agree with previous reports that scorpion venom inhibited the growth of lymphoma $(3,9)$, leukemia (10), neuroblastoma (4), gliomas (11-13), breast cancer (14) and prostate cancer $(15,16)$.

It is well known that cell proliferation is closely related to cell cycle distribution. Under normal conditions, cells are believed to be in the G0 phase in most mammals. Cells progress through the cell cycle phase from G0/G1 to $\mathrm{S}$ after stimulation from extracellular signals. It was demonstrated that scorpion venom induced cell cycle arrest mainly in the G0/G1 phase and decreased in the S phase (3). The analysis of cell cycle distribution in the present study also showed that SVCIII inhibited cell proliferation with cell cycle arrest at the G1 phase and reduced transition to the $S$ phase and G2/M phases of the cell cycle in a dose-dependent manner. This reinforces the evidence that suppression of cell cycle transition is involved in the SVCIII-induced antitumor action in human leukemia cells.

$\mathrm{NF}-\kappa \mathrm{B}$ plays a pivotal role in physiological immune reactions, as well as in the onset and maintenance of malignancies (17-20). It targets many genes that promote tumor progression, cell survival, proliferation, angiogenesis and metastasis (21-23). Aberrant or persistent activation of $\mathrm{NF}-\kappa \mathrm{B}$ is believed to be an important mechanism in the generation of various tumor types $(24,25)$. In this study, we investigated the activity of $\mathrm{NF}-\kappa \mathrm{B}$ using the luciferase reporter gene and EMSA. Results showed that SVCIII inhibited the activity of $\mathrm{NF}-\kappa \mathrm{B}$ in a dose-dependent manner as well. This suggests that SVCIII prevents the binding of $\mathrm{NF}-\kappa \mathrm{B}$ to its target gene, and thus downregulates the expression of $\mathrm{NF}-\kappa \mathrm{B}$-regulated gene products.

$\mathrm{NF}-\kappa \mathrm{B}$ is expressed in the cytoplasm of virtually all cell types. $\mathrm{NF}-\kappa \mathrm{B}$ activation is initiated by the signal-induced degradation of $\mathrm{I} \kappa \mathrm{B}$ proteins $(26,27)$. In the classical $\mathrm{NF}-\kappa \mathrm{B}$ signaling pathway, IкB proteins are phosphorylated by an activated I $\mathrm{B}$ kinase (IKK) complex and then degraded by the proteasome. The degradation of $\mathrm{I} \kappa \mathrm{B}$ allows $\mathrm{NF}-\kappa \mathrm{B}$ protein to translocate to the nucleus and bind to their cognate DNA binding sites to regulate the transcription of many genes $(28,29)$. We found that the suppression of NF- $\kappa \mathrm{B}$ activation was accompanied by inhibition of I $\mathrm{BB} \alpha$ phosphorylation and degradation. Moreover, SVCIII also inhibited p65 nuclear translocation. Therefore, the inhibition of cell proliferation by SVCIII may be associated with downregulation of constitutive $\mathrm{NF}-\kappa \mathrm{B}$ activation.

It is clear that $\mathrm{NF}-\kappa \mathrm{B}$ transcription factor regulates expression of various genes, including cyclin D1 which has been linked with proliferation of tumor cells. Cyclin D1 modulates the cell cycle transition from G1 to $\mathrm{S}$ phase and is overexpressed in a variety of human malignancies $(30,31)$. To reveal the inhibitory mechanism of SVCIII on cell proliferation, we investigated the effect of this compound on the cell cycle. It was found that treatment with SVCIII significantly inhibited the expression of cyclin D1 in a dose-dependent manner. These results suggest a molecular mechanism for the manner in which SVCIII suppresses tumor cell proliferation. Further studies are required to clarify the effects of SVCIII on other signaling pathways.

In conclusion, this study has demonstrated that SVCIII suppresses cell proliferation and cell cycle arrest at the 
G1 phase by targeting the NF- $\mathrm{B}$ signal pathway in THP-1 and Jurkat cells. This suggests that SVCIII may have a potential and/or adjuvant therapeutic application in the treatment of human leukemia.

\section{Acknowledgements}

This research was funded by the Education Department of Henan Province, P.R. China (No. 2010A310005). We thank Cang-bao $\mathrm{Xu}$ for linguistic advice. We also thank Dr Luan Haojiang of the US National Institutes of Health for his generous gift of the NF- $\mathrm{KB}$ luciferase reporter plasmid.

\section{References}

1. Batista CVF, Pozo LD, Zamudio FZ, Contreras S, Becerril B,Wanke E and Possani LD: Proteomics of the venom from the Amazonian scorpion Tityus cambridgei and the role of prolines on mass spectrometry analysis of toxins. J Chromatogr B Analyt Technol Biomed Life Sci 803: 55-66, 2004.

2. Zargan J, Sajad M, Umar S, Naime M, Ali S and Khan HA: Scorpion (Androctonus crassicauda) venom limits growth of transformed cells (SH-SY5Y and MCF-7) by cytotoxicity and cell cycle arrest. Exp Mol Pathol 91: 447-454, 2011.

3. Gao F, Li H, Chen YD, Yu XN, Wang R and Chen XL: Upregulation of PTEN involved in scorpion venom-induced apoptosis in a lymphoma cell line. Leuk Lymphoma 50: 633-641, 2009.

4. Zargan J, Sajad M, Umar S, Naime M, Ali S and Khan HA: Scorpion (Odontobuthus doriae) venom induces apoptosis and inhibits DNA synthesis in human neuroblastoma cells. Mol Cell Biochem 348: 173-181, 2011.

5. Hayden MS, West AP and Ghosh S: NF- $\mathrm{BB}$ and the immune response. Oncogene 25: 6758-6780, 2006.

6. Garg A and Aggarwal BB: Nuclear transcription factor-kappaB as a target for cancer drug development. Leukemia 16: 1053-1068, 2002.

7. Escárcega RO, Fuentes-Alexandro S, García-Carrasco M, Gatica A and Zamora A: The transcription factor nuclear factor- $\kappa \mathrm{B}$ and cancer. Clin Oncol (R Coll Radiol) 19: 154-161, 2007.

8. Hanahan D and Weinberg RA: The hallmarks of cancer. Cell 100: $57-70,2000$

9. Gupta SD, Gomes A, Debnath A, Saha A and Gomes A: Apoptosis induction in human leukemic cells by a novel protein Bengalin, isolated from Indian black scorpion venom: through mitochondrial pathway and inhibition of heat shock proteins Chem Biol Interact 183: 293-303, 2010.

10. Das Gupta S, Debnath A, Saha A, Giri B, Tripathi G, Vedasiromoni JR and Gomes A: Indian black scorpion (Heterometrus bengalensis Koch) venom induced antiproliferative and apoptogenic activity against human leukemic cell lines U937 and K562. Leukemia Res 31: 817-825, 2007.

11. Fan S, Sun Z, Jiang D, Dai C, Ma Y, Zhao Z, Liu H, Wu Y, Cao Z and $\mathrm{Li} \mathrm{W}$ : BmKCT toxin inhibits glioma proliferation and tumor metastasis. Cancer Lett 291: 158-166, 2010.

12. Fu YJ, Yin LT, Liang AH, Zhang CF, Wang W, Chai BF, Yang JY and Fan XJ: Therapeutic potential of chlorotoxin-like neurotoxin from the Chinese scorpion for human gliomas. Neurosci Lett 412: 62-67, 2007.

13. Wang WX and Ji YH: Scorpion venom induces glioma cell apoptosis in vivo and inhibits glioma tumor growth in vitro. J Neurooncol 73: 1-7, 2005.
14. D'Suze G, Rosales A, Salazar V and Sevcik C: Apoptogenic peptides from Tityus discrepans scorpion venom acting against the SKBR3 breast cancer cell line. Toxicon 56: 1497-1505, 2010.

15. Zhang YY, Wu LC, Wang ZP, Wang ZX, Jia Q, Jiang GS and Zhang WD: Anti-proliferation effect of polypeptide extracted from scorpion venom on human prostate cancer cells in vitro. J Clin Med Res 1: 24-31, 2009.

16. Omran MAA: In vitro anticancer effect of scorpion Leiurus quinquestriatus and Egyptian Cobra venom on human breast and prostate cancer cell lines. J Med Sci 3: 66-86, 2003.

17. Bonizzi G and Karin M: The two NF-kappaB activation pathways and their role in innate and adaptive immunity. Trends Immunol 25: 280-288, 2004.

18. Yamamoto M and Takeda K: Role of nuclear IkappaB proteins in the regulation of host immune responses. J Infect Chemother 14: 265-269, 2008.

19. Wu Y and Zhou BP: TNF-alpha/NF-kappaB/Snail pathway in cancer cell migration and invasion. Br J Cancer 102: 639-644, 2010.

20. Sarkar FH, Li Y, Wang Z and Kong D: NF-kappaB signaling pathway and its therapeutic implications in human diseases. Int Rev Immunol 27: 293-319, 2008.

21. Nishikori $\mathrm{M}$ : Classical and alternative $\mathrm{NF}-\kappa \mathrm{B}$ activation pathways and their roles in lymphoid malignancies. J Clin Exp Hematopathol 45: 15-24, 2005.

22. Wong JH, Lui VW, Umezawa K, Ho Y, Wong EY, Ng MH, Cheng SH, Tsang CM, Tsao SW and Chan AT: A small molecule inhibitor of NF-kappaB, dehydroxymethylepoxyquinomicin (DHMEQ), suppresses growth and invasion of nasopharyngeal carcinoma (NPC) cells. Cancer Lett 287: 23-32, 2010.

23. Warfel JM and D'Agnillo F: Anthrax lethal toxin enhances TNF-induced endothelial VCAM-1 expression via an IFN regulatory factor-1-dependent mechanism. J Immunol 180: 7516-7524, 2008

24. Qiao Q, Nozaki Y, Sakoe K, Komatsu N and Kirito K: NF-кB mediates aberrant activation of HIF-1 in malignant lymphoma. Exp Hematol 38: 1199-1208, 2010.

25. Huber AV, Saleh L, Prast J, Haslinger P and Knöfler M: Human chorionic gonadotrophin attenuates NF-kappaB activation and cytokine expression of endometriotic stromal cells. Mol Hum Reprod 13: 595-604, 2007.

26. Karin M and Ben-Neriah Y: Phosphorylation meets ubiquitination: the control of NF-kB activity. Annu Rev Immunol 18: 621-663, 2000

27. Korn SH, Wouters EF, Vos N and Janssen-Heininger YM: Cytokine-induced activation of nuclear factor-kappa $\mathrm{B}$ is inhibited by hydrogen peroxide through oxidative inactivation of IkappaB kinase. J Biol Chem 276: 35693-35700, 2001.

28. Kumar A, Takada Y, Boriek AM and Aggarwal BB: Nuclear factor-кB: its role in health and disease. J Mol Med 82: 434-448, 2004.

29. Sethi G, Sung B and Aggarwal BB: Nuclear factor-kappaB activation: from bench to bedside. Exp Biol Med (Maywood) 233: 21-31, 2008.

30. Biliran H Jr, Wang Y, Banerjee S, Xu H, Heng H, Thakur A, Bollig A, Sarkar FH and Liao JD: Overexpression of cyclin D1 promotes tumor cell growth and confers resistance to cisplatinmediated apoptosis in an elastase-myc transgene-expressing pancreatic tumor cell line. Clin Cancer Res 11: 6075-6086, 2005.

31. Sung B, Ahn KS and Aggarwal BB: Noscapine, a benzylisoquinoline alkaloid, sensitizes leukemic cells to chemotherapeutic agents and cytokines by modulating the NF-kappaB signaling pathway. Cancer Res 70: 3259-3268, 2010. 